OPEN ACCESS

Edited by:

Frank Kirchhoff,

University of Saarland, Germany

Reviewed by:

Eng-Ang Ling,

National University of Singapore,

Singapore

Aviva Jane Symes,

Uniformed Services University of the Health Sciences, USA

${ }^{*}$ Correspondence: Francisco S. Guimaraes fsguimar@fmrp.usp.br

Specialty section: This article was submitted to Neurotrauma,

a section of the journal

Frontiers in Neurology

Received: 28 October 2015 Accepted: 14 January 2016

Published: 28 January 2016

Citation:

Lisboa SF, Gomes FV, Guimaraes FS and Campos AC (2016) Microglial

Cells as a Link between

Cannabinoids and the Immune Hypothesis of Psychiatric Disorders.

Front. Neurol. 7:5.

doi: 10.3389/fneur.2016.00005

\section{Microglial Cells as a Link between Cannabinoids and the Immune Hypothesis of Psychiatric Disorders}

\author{
Sabrina F. Lisboa ${ }^{1,2}$, Felipe V. Gomes ${ }^{3}$, Francisco S. Guimaraes ${ }^{1,2 *}$ and Alline C. Campos ${ }^{1,2}$ \\ ${ }^{1}$ Department of Pharmacology, Medical School of Ribeirão Preto, University of São Paulo, Ribeirão Preto, Brazil, ${ }^{2}$ Center of \\ Interdisciplinary Research on Applied Neurosciences (NAPNA), University of São Paulo, Ribeirão Preto, Brazil, ${ }^{3}$ Department \\ of Neuroscience, University of Pittsburgh, Pittsburgh, PA, USA
}

Psychiatric disorders are one of the leading causes of disability worldwide. Although several therapeutic options are available, the exact mechanisms responsible for the genesis of these disorders remain to be fully elucidated. In the last decade, a body of evidence has supported the involvement of the immune system in the pathophysiology of these conditions. Microglial cells play a significant role in maintaining brain homeostasis and surveillance. Dysregulation of microglial functions has been associated with several psychiatric conditions. Cannabinoids regulate the brain-immune axis and inhibit microglial cell activation. Here, we summarized evidence supporting the hypothesis that microglial cells could be a target for cannabinoid influence on psychiatric disorders, such as anxiety, depression, schizophrenia, and stress-related disorders.

Keywords: microglia, glia, cannabinoids, anxiety, depression, schizophrenia

\section{INTRODUCTION}

\section{Microglial Cells and Psychiatric Disorders}

Over the last 20 years, both the innate and adaptive components of the immune system have been associated with the development of psychiatric disorders, such as depression (1) and schizophrenia (2). However, the mechanisms involved in this association are not altogether clear. Although a full review of these mechanisms would be out of the scope of this mini-review, recent evidence indicates that microglial cells could be important players in this complex puzzle and future targets for the treatment of these disorders (3).

Microglial cells are macrophage-like cells involved in immune surveillance of the central nervous system (CNS) and are a major source of inflammatory mediators in the brain (4). They originate from primitive myeloid progenitors before embryonic day 8 and from infiltrating myeloid cells during embryonic and postnatal development $(5,6)$. Microglia also contributes to CNS homeostasis and plasticity by removing redundant synapses and eliminating dying neurons; modulating neurotransmitter release and neurogenesis; and producing neurotrophic factors $(7,8)$.

During processes that challenge the brain milieu microglial cells proliferate and change their morphology from surveillance (ramified form) to executive and phagocytic state (amoeboid form, activated microglia) (9). Similar to peripheral macrophages, microglial cells assume at least two distinct states of polarization: M1, a profile that secretes proinflammatory cytokines, and M2, a pro-resolution state (4). The activated microglia releases proinflammatory mediators that, along with its phagocytic activity, may lead to brain damage and contribute to the development of psychiatric disorders (4). 


\section{Immune System, Microglia, Anxiety, and Stress-Related Disorders}

Stressful experiences such as social defeat activate long-lasting peripheral and central immune response (10-12) and induce microglial activation, myelopoiesis in the bone marrow and spleen, infiltration of monocytes into the brain and neuroinflammation (12-14).

In humans, posttraumatic stress disorder (PTSD) patients present increased peripheral levels of cytokines, in basal and inflammatory conditions $(15,16)$. Also, although no longer classified as an anxiety disorder, alterations in the immune system of patients with obsessive-compulsive disorder have also been reported $(17,18)$.

The activation and morphological changes of microglial cells associated with neuroinflammatory states have been recently found to depend on changes induced by stress, including the engagement of glucocorticoids and $\beta$-adrenergic receptors (19).

Pharmacological strategies to suppress microglial activity support the involvement of these cells in the development of diseaseor stress-induced neuroinflammation and behavioral alterations $(20-22)$. Minocycline is a tetracycline-derived antibiotic with central anti-inflammatory properties that readily crosses the blood-brain barrier $(23,24)$. It attenuates microglial activation, neuroinflammation, synaptic plasticity, neurogenesis, and behavioral changes in animal models of stress-related disorders $(19,22,25-27)$ and after systemic lipopolysaccharides (LPSs) administration $(28,29)$. The mechanisms of minocycline antiinflammatory effects are not clear, but may involve facilitation of endocannabinoid (eCB) signaling, since they can be prevented by $\mathrm{CB} 1$ or $\mathrm{CB} 2$ receptor antagonists (30). However, its effects in patients with anxiety disorders are still unknown.

Propranolol, a $\beta$-adrenergic receptor antagonist, also attenuates anxiety-like behavior, stress-induced brain proinflammatory profile (including infiltration of peripheral macrophages into the brain and microglial activation) $(31,32)$, and the increase in bone marrow monocytes progenitors (33). These effects could be due to an inhibitory effect on stress-induced peripheral immune system activation (12). Anti-inflammatory effects have also been described for antidepressant drugs after clinical and preclinical studies (34-36).

Overall, these results suggest that modulation of microglial proinflammatory profile, either centrally or by interference with peripheral sympathetic activity, could induce anxiolytic and antistress effects.

\section{Immune System, Microglia, and Depression}

Patients with mood disorders exhibit an activated inflammatory status (37-39), characterized by increases in the number of circulating lymphocytes and macrophages and proinflammatory cytokines (40). Treatment of inflammatory conditions with interferon- $\alpha$ induces depressive symptoms and decreases serotonin levels in the prefrontal cortex of patients (41). These effects could be related to central activation of the enzyme indoleamine 2,3-dioxygenase (IDO) $(42,43)$. Proinflammatory cytokines are proposed to activate IDO that, by interfering with tryptophan/ kynurenine metabolism, decreases serotonin levels and facilitates the production of quinolinic acid, an $N$-methyl-D-aspartate (NMDA) receptor agonist $(40,44)$. Microglial and astrocyte cells control IDO activity. Moreover, activated microglia and infiltrated macrophages have a high capacity for synthesizing quinolinic acid (45). Victims of suicide with the history of affective disorder have increased density of activated phagocytes in the ventral prefrontal white matter (46) and upregulation of the gene IBA1, associated with phenotypic changes in microglia, and MCP-1, a chemokine responsible for attracting monocytes, in the dorsal anterior cingulate $(47,48)$. Besides the increased number of activated microglial cells are reported in the hippocampus of bipolar patients (49).

Antidepressant drugs are reported to inhibit IL-6 $(50,51)$ and TNF- $\alpha$ production (52). Antidepressants inhibit LPS-stimulated microglia (36). Moreover, fluoxetine prevents IKB- $\alpha$ degradation and NF- $\mathrm{kB}$ nuclear translocation (53), while lithium decreases LPS-induced microglial activation through the PI3K/Akt/FoxO1 signaling pathway (54). Corroborating these findings, studies suggest that anti-inflammatory drugs as add-on therapy to antidepressant medication may boost depression treatment (55-57).

Stressful experiences are highly associated with predisposition for both depression episodes and immune dysfunction $(58,59)$. Stress activates microglia in the prefrontal cortex, amygdala, and hippocampus of mice (60) and impairs synaptic plasticity by reducing neuronal activity and decreasing dendritic spine density (61). The high levels of proinflammatory cytokines secreted by microglia downregulate neurotrophic factors, intracellular growth pathways, and neurogenesis $(61,62)$, in which mechanisms believe to be downregulated in depressive states.

\section{Immune System, Microglia, and Schizophrenia}

Increased expression of inflammatory markers in blood and brain tissues (63-65) and changes in genes that control the expression of immune system components have been described in schizophrenia patients (66). Prenatal exposure to inflammatory agents increases the risk for schizophrenia development (67) and metaanalyses indicate the potential use of anti-inflammatory drugs as adjunct treatment in schizophrenia (68).

Postmortem brains of schizophrenia patients present activation and increased cellular density of microglia (69-71). The latter finding has been confirmed by positron emission tomography studies using in vivo markers of activated microglia (72-74). Additionally, elevated microglial activity is also observed in people at ultra high risk of psychosis and is associated with symptom severity, suggesting a link between microglial activation and the risk of psychosis (74). Increased microglial activation is also observed in animal models of schizophrenia $(75,76)$. Although it is unclear how changes in microglial activity result in schizophrenia symptoms, there seems to be an association between microglial activation and negative and cognitive symptoms (77, 78). In line with this proposition, minocycline improved negative symptoms and cognitive function as an add-on treatment in schizophrenia patients $(77,79,80)$. Antipsychotic-like effects of minocycline have also been observed in preclinical studies (81, 82). Together, these results suggest that inhibition of microglial activation may improve schizophrenia symptoms. 


\section{CANNABINOIDS AS IMMUNOMODULATORS IN THE CENTRAL NERVOUS SYSTEM}

The eCB system was initially described in the late 1980s after the identification of specific receptors (83). It now comprises the cannabinoid receptor types 1 (CB1) and 2 (CB2), their endogenous ligands anandamide (AEA) and 2-arachidonoylglycerol (2-AG), and the enzymes responsible for their synthesis and degradation (84-86).

In the CNS, eCBs modulate synaptic function and act as a homeostatic mechanism on HPA axis (87). During stressful or threatening situations, eCBs favor HPA axis activation through the amygdala. Glucocorticoids, by enhancing the production of $\mathrm{eCB}$, modulate glutamatergic and GABAergic neurotransmission via CB1 receptors (87). These receptors are highly expressed in presynaptic terminals and their activation suppresses the release of several neurotransmitters, such as glutamate, GABA, and serotonin (88). CB1 is also expressed in astrocytes (89), oligodendrocytes (90), and neural precursor cells, which also expresses CB2 receptors (91). In addition to $\mathrm{CB} 1, \mathrm{CB} 2$ receptors are constitutively expressed in microglia cells (92) and its expression increases in inflammatory conditions (93). These receptors have been proposed as key regulators of the immune functions, including microglial activation (94-96). They are overexpressed during neurodegenerative diseases, such as Alzheimer's disease and multiple sclerosis, conditions in which activated microglia is observed (97). Recently, Mecha et al. (98) demonstrate that the eCB system, by activating CB2 receptors, not only influences the migration, proliferation, and release of proinflammatory mediators of microglial cells but also affects their phagocytic function and drive these glial cells to the M2 state.

2-Arachidonoylglycerol can protect neurons exposed to harmful insults by acting as an endogenous inhibitor of cyclooxygenase-2 (COX-2) (99), whereas AEA inhibits TNF- $\alpha$-induced NF- $\kappa \mathrm{B}$ activation by direct inhibition of the I $\kappa \mathrm{B}$ kinase (100). Pharmacological inhibition of AEA hydrolysis reduces microglial activation, nitric oxide levels, and the production of inflammatory mediators (101). Under pathological conditions, microglia cells produce large amounts of eCBs, which could facilitate an anti-inflammatory phenotype of microglia (92). Enzymes controlling eCB tone also plays an important neuroprotective role during neuroinflammatory process (97). Supporting the involvement of eCBs in immune modulation, the neuroprotective effect and inhibition of microglial activation induced by minocycline were prevented by $\mathrm{CB} 1$ and $\mathrm{CB} 2$ receptor antagonists in a rodent model of traumatic brain injury (30).

Exogenous cannabinoids can also modulate microglia activation $(97,102,103)$. They reduce the binding of transcription factors to CRE and NF- $\mathrm{KB}$ in immune cells (104) and inhibit cytokine and chemokine production (105). WIN55,212-2, a mixed CB1/CB2 receptor agonist, reduced brain mRNA expression of proinflammatory cytokines, such as TNF- $\alpha$ and IL- 6 , in a viral model of multiple sclerosis (106) and in the Alzheimer's disease model of $\mathrm{A} \beta$ amyloid injection $(107,108)$. Moreover, WIN55,212-2 also decreased the number of activated microglia related to $\mathrm{A} \beta$ administration (107) or the aging process in rats (102).

\section{Cannabinoids, Microglia, and Anxiety Disorder}

Overexpression of $\mathrm{CB} 1$ and $\mathrm{CB} 2$ receptors, or their acute pharmacological activation, promotes anxiolytic-like effects $(109,110)$, whereas their genetic deletion or pharmacological blockade causes opposite results $(111,112)$. These receptors also attenuate the increased proinflammatory profile observed in the frontal cortex after subchronic stress in mice $(113,114)$, reducing microglial activation and proliferation (95, 115-117).

Cannabinoids could also attenuate anxiety by modulating the release of IL-1ra, the endogenous antagonist of IL-1 $\beta$, by glial cells in response to glutamate (118), and by interfering with the HPA axis (119). In the latter case, glucocorticoids modulate microglial activation induced by stressors $(120,121)$ and suppress hippocampal and amygdala eCB signaling (122).

\section{Cannabinoids, Microglia, and Depression}

Lipopolysaccharide induces "sickness behavior" in rodents, a syndrome that shows some similarity with depressive symptoms and depends on prolonged cytokines release and microglial activation (123, 124). Accordingly, using LPS as inflammatory stimulus, cannabinoids reduced the number of circulating lymphocyte, corticosterone levels (125), and the release of IL-1 $\beta$, TNF- $\alpha$, and iNOS expression in vitro (126). Moreover, the long-lasting behavioral deficits induced by LPS are prevented by the administration of THC (127) or cannabidiol (CBD) (108). As discussed above, in addition to interfere with HPA axis (119), cannabinoids can directly decrease microglial activation and attenuate stressinduced neuroinflammatory states $(108,125,126)$.

Although the specific contribution of $\mathrm{CB} 1$ and $\mathrm{CB} 2$ receptors for the aforementioned anti-inflammatory effects is still unclear, the neuroprotective effects of CB2 agonists are associated with a decrease in the number of activated microglial cells (107). In vitro studies indicate that these receptors, located at microglial cells, facilitate the production of anti-inflammatory mediators (128). Considering the pieces of evidence suggesting that depression could be a "microglial disease," these results point to CB2 receptors located at this cells as possible targets for future antidepressant treatments.

\section{Cannabinoids, Microglia, and Schizophrenia}

Adolescent cannabis exposure represents a risk factor for developing schizophrenia later in life (129). Besides the long-lasting changes in neuronal activity induced by adolescent cannabinoid exposure $(76,130)$, increased microglial activation in the prefrontal cortex (131) and hippocampus of adult rats have also been observed (132). Moreover, ibudilast (AV411), a non-selective phosphodiesterase inhibitor that suppresses glial cell activation (133), prevents the development of behavioral changes induced by adolescent THC exposure (131).

Unlike THC, CBD is a phytocannabinoid devoid of psychotomimetic activity that present antipsychotic activity (134). The mechanism of action involved in this effect is not entirely understood. However, the anti-inflammatory and neuroprotective effects of this drug (135) may contribute to its beneficial effects in 


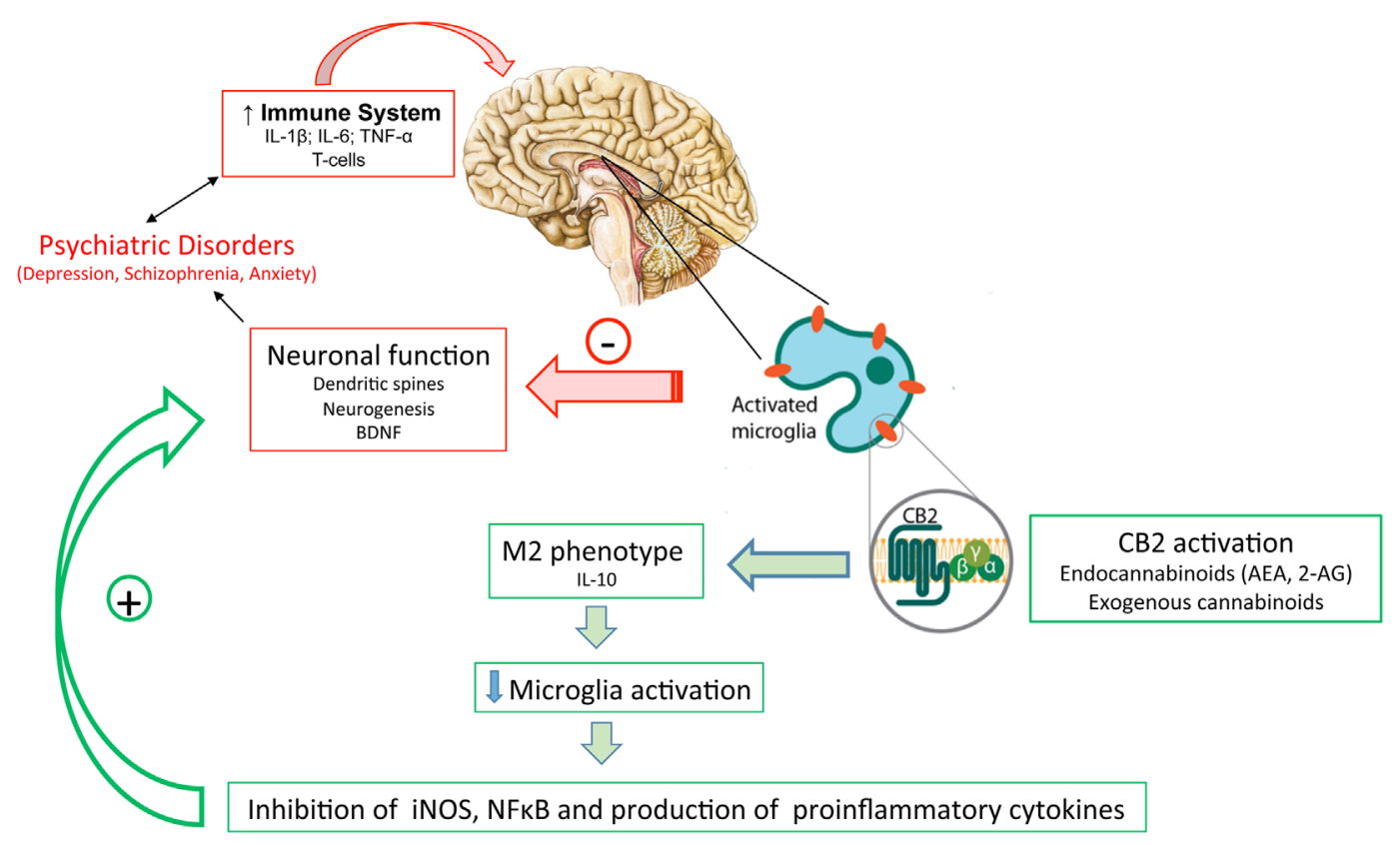

FIGURE 1 | The inflammatory status observed in patients with psychiatric disorders might lead to activated microglia and neuronal/synaptic damage. Activation of cannabinoids receptors (mainly CB2 in activated microglia) by (endo)cannabinoids would drive microglia to a M2 (pro-resolution) state, decreasing the production of proinflammatory mediators and protecting neurons from damage.

schizophrenia. Repeated treatment with CBD-attenuated behavioral deficits and the percentage of Iba-1-positive microglial cells with a reactive phenotype in the medial prefrontal cortex and dorsal hippocampus of mice chronically treated with the NMDA receptor antagonist MK-801 (136). CBD treatment also attenuated the decreased number of GABAergic parvalbumin-positive cells in the medial prefrontal cortex, which could, by reducing inhibitory tonus in this region, facilitate glutamate release and lead to microglial activation (137). Interestingly, schizophrenia patients with a higher inflammatory state had more deficits in GABAergic neuron-related mRNAs, including GAD67 and parvalbumin (138).

Regarding the eCB system, whereas higher levels of 2-AG have been observed in the prefrontal cortex, hippocampus, and cerebellum of schizophrenia patients, AEA levels are lower (139). Moreover, increased AEA levels in the cerebrospinal fluid correlate negatively with psychotic symptoms (140) and the antipsychotic effect of CBD was associated with increased AEA serum levels. This latter effect likely reflects $\mathrm{CBD}$ inhibition of the FAAH enzyme, responsible for AEA degradation (141). Increases in eCBs may contribute to defense mechanisms through accumulation of anti-inflammatory microglia phenotype (92). Thus, the pharmacological inhibition of eCB hydrolysis may be a useful approach in the schizophrenia treatment.

As aforementioned, CB2 receptors are expressed on microglia and its expression is strongly upregulated when these cells are activated. Schizophrenia has been associated with single nucleotide polymorphisms in the $\mathrm{CB} 2$ receptor gene that reduce its expression and functionality (142). Decreased expression of CB2 receptors in isolated peripheral blood mononuclear cells is found during first-episode psychosis (143). However, no study has evaluated changes on $\mathrm{CB} 2$ receptor expression in microglia cells in the brain of schizophrenia patients. In rodents, pharmacological or genetic CB2 receptor blockade increases susceptibility for developing schizophrenia-like symptoms $(111,142)$. Additionally, a CB2 receptor agonist reversed sensorimotor gating deficits in mice induced by MK-801 (144). However, the involvement of microglial CB2 receptors in these effects is unknown.

\section{CONCLUSION}

A large body of evidence supports the involvement of neuroinflammatory mechanisms, including microglial activation, in the pathophysiology of psychiatric disorders. Drugs that interfere with these mechanisms, such as cannabinoids, could be a novel and important new pathway for the treatment of these disorders (Figure 1). Despite these pieces of evidence, few studies have yet directly investigated if interference with microglial cell activation is essential for the therapeutic effects of cannabinoids in psychiatric disorders. Additional studies, therefore, are needed to test this hypothesis.

\section{AUTHOR CONTRIBUTIONS}

All authors have contributed in the writing part of this mini-review.

\section{FUNDING}

We thank the financial support from Fapesp, Capes, and CNPq. 


\section{REFERENCES}

1. Haapakoski R, Ebmeier KP, Alenius H, Kivimaki M. Innate and adaptive immunity in the development of depression: an update on current knowledge and technological advances. Prog Neuropsychopharmacol Biol Psychiatry (2015) 66:63-72. doi:10.1016/j.pnpbp.2015.11.012

2. Watkins CC, Andrews SR. Clinical studies of neuroinflammatory mechanisms in schizophrenia. Schizophr Res (2015). doi:10.1016/j.schres.2015.07.018

3. Yirmiya R, Rimmerman N, Reshef R. Depression as a microglial disease. Trends Neurosci (2015) 38:637-58. doi:10.1016/j.tins.2015.08.001

4. Prinz M, Priller J. Microglia and brain macrophages in the molecular age: from origin to neuropsychiatric disease. Nat Rev Neurosci (2014) 15:300-12. doi:10.1038/nrn3722

5. Alliot F, Godin I, Pessac B. Microglia derive from progenitors, originating from the yolk sac, and which proliferate in the brain. Brain Res Dev Brain Res (1999) 117:145-52. doi:10.1016/S0165-3806(99)00113-3

6. Ginhoux F, Greter M, Leboeuf M, Nandi S, See P, Gokhan S, et al. Fate mapping analysis reveals that adult microglia derive from primitive macrophages. Science (2010) 330:841-5. doi:10.1126/science.1194637

7. Ziv Y, Avidan H, Pluchino S, Martino G, Schwartz M. Synergy between immune cells and adult neural stem/progenitor cells promotes functional recovery from spinal cord injury. Proc Natl Acad Sci US A (2006) 103:13174-9. doi:10.1073/pnas.0603747103

8. Beumer W, Gibney SM, Drexhage RC, Pont-Lezica L, Doorduin J, Klein HC, et al. The immune theory of psychiatric diseases: a key role for activated microglia and circulating monocytes. J Leukoc Biol (2012) 92:959-75. doi:10.1189/jlb.0212100

9. Ransohoff RM, Cardona AE. The myeloid cells of the central nervous system parenchyma. Nature (2010) 468:253-62. doi:10.1038/nature09615

10. Avitsur R, Powell N, Padgett DA, Sheridan JF. Social interactions, stress, and immunity. Immunol Allergy Clin North Am (2009) 29:285-93. doi:10.1016/j. iac.2009.02.006

11. Wohleb ES, McKim DB, Shea DT, Powell ND, Tarr AJ, Sheridan JF, et al. Re-establishment of anxiety in stress-sensitized mice is caused by monocyte trafficking from the spleen to the brain. Biol Psychiatry (2014) 75:970-81. doi:10.1016/j.biopsych.2013.11.029

12. Reader BF, Jarrett BL, McKim DB, Wohleb ES, Godbout JP, Sheridan JF. Peripheral and central effects of repeated social defeat stress: monocyte trafficking, microglial activation, and anxiety. Neuroscience (2015) 289:429-42. doi:10.1016/j.neuroscience.2015.01.001

13. Wohleb ES, McKim DB, Sheridan JF, Godbout JP. Monocyte trafficking to the brain with stress and inflammation: a novel axis of immune-to-brain communication that influences mood and behavior. Front Neurosci (2015) 8:447. doi:10.3389/fnins.2014.00447

14. McKim DB, Patterson JM, Wohleb ES, Jarrett BL, Reader BF, Godbout JP, et al. Sympathetic release of splenic monocytes promotes recurring anxiety following repeated social defeat. Biol Psychiatry (2015). doi:10.1016/j. biopsych.2015.07.010

15. Rohleder N, Nater UM, Wolf JM, Ehlert U, Kirschbaum C. Psychosocial stress-induced activation of salivary alpha-amylase: an indicator of sympathetic activity? Ann N Y Acad Sci (2004) 1032:258-63. doi:10.1196/ annals. 1314.033

16. Lindqvist D, Wolkowitz OM, Mellon S, Yehuda R, Flory JD, Henn-Haase $\mathrm{C}$, et al. Proinflammatory milieu in combat-related PTSD is independent of depression and early life stress. Brain Behav Immun (2014) 42:81-8. doi:10.1016/j.bbi.2014.06.003

17. da Rocha FF, Correa H, Teixeira AL. Obsessive-compulsive disorder and immunology: a review. Prog Neuropsychopharmacol Biol Psychiatry (2008) 32:1139-46. doi:10.1016/j.pnpbp.2007.12.026

18. Cappi C, Muniz RK, Sampaio AS, Cordeiro Q, Brentani H, Palacios SA, et al. Association study between functional polymorphisms in the TNF-alpha gene and obsessive-compulsive disorder. Arq Neuropsiquiatr (2012) 70:87-90. doi:10.1590/S0004-282X2012000200003

19. Yuan TF, Hou G, Zhao Y, Arias-Carrion O. Commentary: the effects of psychological stress on microglial cells in the brain. CNS Neurol Disord Drug Targets (2015) 14:304-8. doi:10.2174/1871527314666150123122851
20. Kim HS, Suh YH. Minocycline and neurodegenerative diseases. Behav Brain Res (2009) 196:168-79. doi:10.1016/j.bbr.2008.09.040

21. Hinwood M, Morandini J, Day TA, Walker FR. Evidence that microglia mediate the neurobiological effects of chronic psychological stress on the medial prefrontal cortex. Cereb Cortex (2012) 22:1442-54. doi:10.1093/ cercor/bhr229

22. Levkovitz Y, Fenchel D, Kaplan Z, Zohar J, Cohen H. Early post-stressor intervention with minocycline, a second-generation tetracycline, attenuates post-traumatic stress response in an animal model of PTSD. Eur Neuropsychopharmacol (2015) 25:124-32. doi:10.1016/j. euroneuro.2014.11.012

23. Colovic M, Caccia S. Liquid chromatographic determination of minocycline in brain-to-plasma distribution studies in the rat. J Chromatogr B Analyt Technol Biomed Life Sci (2003) 791:337-43. doi:10.1016/S1570-0232(03)00247-2

24. Dean OM, Data-Franco J, Giorlando F, Berk M. Minocycline: therapeutic potential in psychiatry. CNS Drugs (2012) 26:391-401. doi:10.2165/11632000-000000000-00000

25. Ekdahl CT, Claasen JH, Bonde S, Kokaia Z, Lindvall O. Inflammation is detrimental for neurogenesis in adult brain. Proc Natl Acad Sci U S A (2003) 100:13632-7. doi:10.1073/pnas.2234031100

26. Pabreja K, Dua K, Sharma S, Padi SS, Kulkarni SK. Minocycline attenuates the development of diabetic neuropathic pain: possible anti-inflammatory and anti-oxidant mechanisms. Eur J Pharmacol (2011) 661:15-21. doi:10.1016/j. ejphar.2011.04.014

27. Taylor AM, Castonguay A, Taylor AJ, Murphy NP, Ghogha A, Cook C, et al. Microglia disrupt mesolimbic reward circuitry in chronic pain. J Neurosci (2015) 35:8442-50. doi:10.1523/JNEUROSCI.4036-14.2015

28. Tomás-Camardiel M, Rite I, Herrera AJ, de Pablos RM, Cano J, Machado A, et al. Minocycline reduces the lipopolysaccharide-induced inflammatory reaction, peroxynitrite-mediated nitration of proteins, disruption of the blood-brain barrier, and damage in the nigral dopaminergic system. Neurobiol Dis (2004) 16:190-201. doi:10.1016/j.nbd.2004.01.010

29. Henry CJ, Huang Y, Wynne A, Hanke M, Himler J, Bailey MT, et al. Minocycline attenuates lipopolysaccharide (LPS)-induced neuroinflammation, sickness behavior, and anhedonia. J Neuroinflammation (2008) 5:15. doi:10.1186/1742-2094-5-15

30. Lopez-Rodriguez AB, Siopi E, Finn DP, Marchand-Leroux C, Garcia-Segura LM, Jafarian-Tehrani M, et al. CB1 and CB2 cannabinoid receptor antagonists prevent minocycline-induced neuroprotection following traumatic brain injury in mice. Cereb Cortex (2015) 25:35-45. doi:10.1093/cercor/ bht202

31. Wohleb ES, Hanke ML, Corona AW, Powell ND, Stiner LM, Bailey MT, et al. Beta-adrenergic receptor antagonism prevents anxiety-like behavior and microglial reactivity induced by repeated social defeat. J Neurosci (2011) 31:6277-88. doi:10.1523/JNEUROSCI.0450-11.2011

32. Hanke ML, Powell ND, Stiner LM, Bailey MT, Sheridan JF. Beta adrenergic blockade decreases the immunomodulatory effects of social disruption stress. Brain Behav Immun (2012) 26:1150-9. doi:10.1016/j.bbi.2012.07.011

33. Powell ND, Sloan EK, Bailey MT, Arevalo JM, Miller GE, Chen E, et al. Social stress up-regulates inflammatory gene expression in the leukocyte transcriptome via beta-adrenergic induction of myelopoiesis. Proc Natl Acad Sci US A (2013) 110:16574-9. doi:10.1073/pnas.1310655110

34. Sutcigil L, Oktenli C, Musabak U, Bozkurt A, Cansever A, Uzun O, et al. Pro- and anti-inflammatory cytokine balance in major depression: effect of sertraline therapy. Clin Dev Immunol (2007) 2007:76396. doi:10.1155/2007/76396

35. Norden DM, Devine R, Bicer S, Jing R, Reiser PJ, Wold LE, et al. Fluoxetine prevents the development of depressive-like behavior in a mouse model of cancer related fatigue. Physiol Behav (2015) 140:230-5. doi:10.1016/j. physbeh.2014.12.045

36. Ramirez K, Shea DT, McKim DB, Reader BF, Sheridan JF. Imipramine attenuates neuroinflammatory signaling and reverses stress-induced social avoidance. Brain Behav Immun (2015) 46:212-20. doi:10.1016/j.bbi.2015.01.016

37. Schlatter J, Ortuno F, Cervera-Enguix S. Differences in interleukins' patterns between dysthymia and major depression. Eur Psychiatry (2001) 16:317-9. doi:10.1016/S0924-9338(01)00585-5 
38. Tuglu C, Kara SH, Caliyurt O, Vardar E, Abay E. Increased serum tumor necrosis factor-alpha levels and treatment response in major depressive disorder. Psychopharmacology (Berl) (2003) 170:429-33. doi:10.1007/ s00213-003-1566-Z

39. Grassi-Oliveira R, Bauer ME, Pezzi JC, Teixeira AL, Brietzke E. Interleukin-6 and verbal memory in recurrent major depressive disorder. Neuro Endocrinol Lett (2011) 32:540-4.

40. Muller N. Immunology of major depression. Neuroimmunomodulation (2014) 21:123-30. doi:10.1159/000356540

41. McNamara RK, Lotrich FE. Elevated immune-inflammatory signaling in mood disorders: a new therapeutic target? Expert Rev Neurother (2012) 12:1143-61. doi:10.1586/ern.12.98

42. Raison CL, Dantzer R, Kelley KW, Lawson MA, Woolwine BJ, Vogt G, et al. CSF concentrations of brain tryptophan and kynurenines during immune stimulation with IFN-alpha: relationship to CNS immune responses and depression. Mol Psychiatry (2010) 15:393-403. doi:10.1038/mp.2009.116

43. Wichers MC, Koek GH, Robaeys G, Verkerk R, Scharpe S, Maes M. IDO and interferon-alpha-induced depressive symptoms: a shift in hypothesis from tryptophan depletion to neurotoxicity. Mol Psychiatry (2005) 10:538-44. doi:10.1038/sj.mp.4001600

44. Kim JS, Schmid-Burgk W, Claus D, Kornhuber HH. Effects of amitriptyline on serum glutamate and free tryptophan in rats. Arch Psychiatr Nervenkr (1970) (1982) 232:391-4. doi:10.1007/BF00345595

45. Heyes MP, Achim CL, Wiley CA, Major EO, Saito K, Markey SP. Human microglia convert l-tryptophan into the neurotoxin quinolinic acid. Biochem $J$ (1996) 320(Pt 2):595-7. doi:10.1042/bj3200595

46. Schnieder TP, Trencevska I, Rosoklija G, Stankov A, Mann JJ, Smiley J, et al. Microglia of prefrontal white matter in suicide. J Neuropathol Exp Neurol (2014) 73:880-90. doi:10.1097/NEN.0000000000000107

47. Steiner J, Walter M, Gos T, Guillemin GJ, Bernstein HG, Sarnyai Z, et al. Severe depression is associated with increased microglial quinolinic acid in subregions of the anterior cingulate gyrus: evidence for an immunemodulated glutamatergic neurotransmission? J Neuroinflammation (2011) 8:94. doi:10.1186/1742-2094-8-94

48. Torres-Platas SG, Cruceanu C, Chen GG, Turecki G, Mechawar N. Evidence for increased microglial priming and macrophage recruitment in the dorsal anterior cingulate white matter of depressed suicides. Brain Behav Immun (2014) 42:50-9. doi:10.1016/j.bbi.2014.05.007

49. Haarman BC, Riemersma-Van der Lek RF, de Groot JC, Ruhe HG, Klein HC, Zandstra TE, et al. Neuroinflammation in bipolar disorder - A [(11) C]-(R)-PK11195 positron emission tomography study. Brain Behav Immun (2014) 40:219-25. doi:10.1016/j.bbi.2014.03.016

50. Xia Z, DePierre JW, Nassberger L. Tricyclic antidepressants inhibit IL-6, IL-1 beta and TNF-alpha release in human blood monocytes and IL-2 and interferon-gamma in T cells. Immunopharmacology (1996) 34:27-37. doi:10.1016/0162-3109(96)00111-7

51. Basterzi AD, Aydemir C, Kisa C, Aksaray S, Tuzer V, Yazici K, et al. IL-6 levels decrease with SSRI treatment in patients with major depression. Hum Psychopharmacol (2005) 20:473-6. doi:10.1002/hup.717

52. Schiepers OJ, Wichers MC, Maes M. Cytokines and major depression. Prog Neuropsychopharmacol Biol Psychiatry (2005) 29:201-17. doi:10.1016/j. pnpbp.2004.11.003

53. Liu D, Wang Z, Liu S, Wang F, Zhao S, Hao A. Anti-inflammatory effects of fluoxetine in lipopolysaccharide(LPS)-stimulated microglial cells. Neuropharmacology (2011) 61:592-9. doi:10.1016/j.neuropharm.2011.04.033

54. Dong H, Zhang X, Dai X, Lu S, Gui B, Jin W, et al. Lithium ameliorates lipopolysaccharide-induced microglial activation via inhibition of tolllike receptor 4 expression by activating the PI3K/Akt/FoxO1 pathway. $J$ Neuroinflammation (2014) 11:140. doi:10.1186/s12974-014-0140-4

55. Nery FG, Monkul ES, Hatch JP, Fonseca M, Zunta-Soares GB, Frey BN, et al. Celecoxib as an adjunct in the treatment of depressive or mixed episodes of bipolar disorder: a double-blind, randomized, placebo-controlled study. Hum Psychopharmacol (2008) 23:87-94. doi:10.1002/hup.912

56. Akhondzadeh S, Jafari S, Raisi F, Nasehi AA, Ghoreishi A, Salehi B, et al. Clinical trial of adjunctive celecoxib treatment in patients with major depression: a double blind and placebo controlled trial. Depress Anxiety (2009) 26:607-61. doi:10.1002/da.20589

57. Guo JY, Li CY, Ruan YP, Sun M, Qi XL, Zhao BS, et al. Chronic treatment with celecoxib reverses chronic unpredictable stress-induced depressive-like behavior via reducing cyclooxygenase-2 expression in rat brain. Eur J Pharmacol (2009) 612:54-60. doi:10.1016/j.ejphar.2009.03.076

58. Bidzinska E. [Premorbid personality characteristics in patients with affective disorders]. Psychiatr Pol (1984) 18:313-8.

59. Dowlati Y, Herrmann N, Swardfager W, Liu H, Sham L, Reim EK, et al. A meta-analysis of cytokines in major depression. Biol Psychiatry (2010) 67:446-57. doi:10.1016/j.biopsych.2009.09.033

60. Delpech JC, Madore C, Nadjar A, Joffre C, Wohleb ES, Laye S. Microglia in neuronal plasticity: influence of stress. Neuropharmacology (2015) 96:19-28. doi:10.1016/j.neuropharm.2014.12.034

61. Kreisel T, Frank MG, Licht T, Reshef R, Ben-Menachem-Zidon O, Baratta MV, et al. Dynamic microglial alterations underlie stress-induced depressive-like behavior and suppressed neurogenesis. Mol Psychiatry (2014) 19:699-709. doi:10.1038/mp.2013.155

62. Campos AC, Vaz GN, Saito VM, Teixeira AL. Further evidence for the role of interferon-gamma on anxiety- and depressive-like behaviors: involvement of hippocampal neurogenesis and NGF production. Neurosci Lett (2014) 578:100-5. doi:10.1016/j.neulet.2014.06.039

63. Kirkpatrick B, Miller BJ. Inflammation and schizophrenia. Schizophr Bull (2013) 39:1174-9. doi:10.1093/schbul/sbt141

64. Fillman SG, Cloonan N, Catts VS, Miller LC, Wong J, McCrossin T, et al. Increased inflammatory markers identified in the dorsolateral prefrontal cortex of individuals with schizophrenia. Mol Psychiatry (2013) 18:206-14. doi:10.1038/mp.2012.110

65. Volk DW, Chitrapu A, Edelson JR, Roman KM, Moroco AE, Lewis DA. Molecular mechanisms and timing of cortical immune activation in schizophrenia. Am J Psychiatry (2015) 172:1112-21. doi:10.1176/appi. ajp.2015.15010019

66. Schizophrenia Working Group of the Psychiatric Genomics Consortium. Biological insights from 108 schizophrenia-associated genetic loci. Nature (2014) 511:42-427. doi:10.1038/nature13595

67. Clarke MC, Tanskanen A, Huttunen M, Whittaker JC, Cannon M. Evidence for an interaction between familial liability and prenatal exposure to infection in the causation of schizophrenia. Am J Psychiatry (2009) 166:1025-30. doi:10.1176/appi.ajp.2009.08010031

68. Sommer IE, van Westrhenen R, Begemann MJ, de Witte LD, Leucht S, Kahn RS. Efficacy of anti-inflammatory agents to improve symptoms in patients with schizophrenia: an update. Schizophr Bull (2014) 40:181-91. doi:10.1093/ schbul/sbt139

69. Bayer TA, Buslei R, Havas L, Falkai P. Evidence for activation of microglia in patients with psychiatric illnesses. Neurosci Lett (1999) 271:126-8. doi:10.1016/S0304-3940(99)00545-5

70. Radewicz K, Garey LJ, Gentleman SM, Reynolds R. Increase in HLA-DR immunoreactive microglia in frontal and temporal cortex of chronic schizophrenics. J Neuropathol Exp Neurol (2000) 59:137-50. doi:10.1093/ jnen/59.2.137

71. Steiner J, Bielau H, Bernstein HG, Bogerts B, Wunderlich MT. Increased cerebrospinal fluid and serum levels of S100B in first-onset schizophrenia are not related to a degenerative release of glial fibrillar acidic protein, myelin basic protein and neurone-specific enolase from glia or neurones. J Neurol Neurosurg Psychiatry (2006) 77:1284-7. doi:10.1136/jnnp.2006.093427

72. van Berckel BN, Bossong MG, Boellaard R, Kloet R, Schuitemaker A, Caspers $\mathrm{E}$, et al. Microglia activation in recent-onset schizophrenia: a quantitative (R)-[11C]PK11195 positron emission tomography study. Biol Psychiatry (2008) 64:820-2. doi:10.1016/j.biopsych.2008.04.025

73. Doorduin J, de Vries EF, Willemsen AT, de Groot JC, Dierckx RA, Klein HC. Neuroinflammation in schizophrenia-related psychosis: a PET study. J Nucl Med (2009) 50:1801-7. doi:10.2967/jnumed.109.066647

74. Bloomfield PS, Selvaraj S, Veronese M, Rizzo G, Bertoldo A, Owen DR, et al. Microglial activity in people at ultra high risk of psychosis and in schizophrenia: an [C]PBR28 PET Brain Imaging Study. Am J Psychiatry (2016) 173:44-52. doi:10.1176/appi.ajp.2015.14101358

75. Ribeiro BM, do Carmo MR, Freire RS, Rocha NF, Borella VC, de Menezes AT, et al. Evidences for a progressive microglial activation and increase in iNOS expression in rats submitted to a neurodevelopmental model of schizophrenia: reversal by clozapine. Schizophr Res (2013) 151:12-9. doi:10.1016/j. schres.2013.10.040

76. Gomes FV, Guimaraes FS, Grace AA. Effects of pubertal cannabinoid administration on attentional set-shifting and dopaminergic hyper- 
responsivity in a developmental disruption model of schizophrenia. Int $J$ Neuropsychopharmacol (2015) 18:1-10. doi:10.1093/ijnp/pyu018

77. Levkovitz Y, Mendlovich S, Riwkes S, Braw Y, Levkovitch-Verbin H, Gal G, et al. A double-blind, randomized study of minocycline for the treatment of negative and cognitive symptoms in early-phase schizophrenia. J Clin Psychiatry (2010) 71:138-49. doi:10.4088/JCP.08m04666yel

78. Ribeiro-Santos A, Lucio Teixeira A, Salgado JV. Evidence for an immune role on cognition in schizophrenia: a systematic review. Curr Neuropharmacol (2014) 12:273-80. doi:10.2174/1570159X1203140511160832

79. Chaudhry IB, Hallak J, Husain N, Minhas F, Stirling J, Richardson P, et al. Minocycline benefits negative symptoms in early schizophrenia: a randomised double-blind placebo-controlled clinical trial in patients on standard treatment. J Psychopharmacol (2012) 26:1185-93. doi:10.1177/0269881112444941

80. Chaves C, Marque CR, Maia-de-Oliveira JP, Wichert-Ana L, Ferrari TB, Santos AC, et al. Effects of minocycline add-on treatment on brain morphometry and cerebral perfusion in recent-onset schizophrenia. Schizophr Res (2015) 161:439-45. doi:10.1016/j.schres.2014.11.031

81. Fujita Y, Ishima T, Kunitachi S, Hagiwara H, Zhang L, Iyo M, et al. Phencyclidine-induced cognitive deficits in mice are improved by subsequent subchronic administration of the antibiotic drug minocycline. Prog Neuropsychopharmacol Biol Psychiatry (2008) 32:336-9. doi:10.1016/j. pnpbp.2007.08.031

82. Mattei D, Djodari-Irani A, Hadar R, Pelz A, de Cossio LF, Goetz T, et al. Minocycline rescues decrease in neurogenesis, increase in microglia cytokines and deficits in sensorimotor gating in an animal model of schizophrenia. Brain Behav Immun (2014) 38:175-84. doi:10.1016/j.bbi.2014.01.019

83. Devane WA, Dysarz FA III, Johnson MR, Melvin LS, Howlett AC. Determination and characterization of a cannabinoid receptor in rat brain. Mol Pharmacol (1988) 34:605-13.

84. Devane WA, Hanus L, Breuer A, Pertwee RG, Stevenson LA, Griffin G, et al. Isolation and structure of a brain constituent that binds to the cannabinoid receptor. Science (1992) 258:1946-9. doi:10.1126/science.1470919

85. Mechoulam R, Ben-Shabat S, Hanus L, Ligumsky M, Kaminski NE, Schatz $\mathrm{AR}$, et al. Identification of an endogenous 2-monoglyceride, present in canine gut, that binds to cannabinoid receptors. Biochem Pharmacol (1995) 50:83-90. doi:10.1016/0006-2952(95)00109-D

86. Katona I, Freund TF. Endocannabinoid signaling as a synaptic circuit breaker in neurological disease. Nat Med (2008) 14:923-30. doi:10.1038/ nm.f. 1869

87. Hillard CJ. Stress regulates endocannabinoid-CB1 receptor signaling. Semin Immunol (2014) 26:380-8. doi:10.1016/j.smim.2014.04.001

88. Moreira FA, Aguiar DC, Campos AC, Lisboa SF, Terzian AL, Resstel LB, et al. Antiaversive effects of cannabinoids: is the periaqueductal gray involved? Neural Plast (2009) 2009:625469. doi:10.1155/2009/625469

89. Navarrete M, Araque A. Endocannabinoids potentiate synaptic transmission through stimulation of astrocytes. Neuron (2010) 68:113-26. doi:10.1016/j. neuron.2010.08.043

90. Mato S, Victoria Sanchez-Gomez M, Matute C. Cannabidiol induces intracellular calcium elevation and cytotoxicity in oligodendrocytes. Glia (2010) 58:1739-47. doi:10.1002/glia.21044

91. Maccarrone M, Guzman M, Mackie K, Doherty P, Harkany T. Programming of neural cells by (endo)cannabinoids: from physiological rules to emerging therapies. Nat Rev Neurosci (2014) 15:786-801. doi:10.1038/nrn3846

92. Stella N. Endocannabinoid signaling in microglial cells. Neuropharmacology (2009) 56(Suppl 1):244-53. doi:10.1016/j.neuropharm.2008.07.037

93. Cabral GA, Marciano-Cabral F. Cannabinoid receptors in microglia of the central nervous system: immune functional relevance. J Leukoc Biol (2005) 78:1192-7. doi:10.1189/jlb.0405216

94. Correa F, Mestre L, Docagne F, Guaza C. Activation of cannabinoid CB2 receptor negatively regulates IL-12p40 production in murine macrophages: role of IL-10 and ERK1/2 kinase signaling. Br J Pharmacol (2005) 145:441-8. doi:10.1038/sj.bjp.0706215

95. Ehrhart J, Obregon D, Mori T, Hou H, Sun N, Bai Y, et al. Stimulation of cannabinoid receptor 2 (CB2) suppresses microglial activation. $J$ Neuroinflammation (2005) 2:29. doi:10.1186/1742-2094-2-29

96. Ashton JC. Cannabinoids for the treatment of inflammation. Curr Opin Investig Drugs (2007) 8:373-84.
97. Bisogno T, Di Marzo V. Cannabinoid receptors and endocannabinoids: role in neuroinflammatory and neurodegenerative disorders. CNS Neurol Disord Drug Targets (2010) 9:564-73. doi:10.2174/187152710793361568

98. Mecha M, Feliu A, Carrillo-Salinas FJ, Rueda-Zubiaurre A, Ortega-Gutierrez $S$, de Sola RG, et al. Endocannabinoids drive the acquisition of an alternative phenotype in microglia. Brain Behav Immun (2015) 49:233-45. doi:10.1016/j. bbi.2015.06.002

99. Du H, Chen X, Zhang J, Chen C. Inhibition of COX-2 expression by endocannabinoid 2-arachidonoylglycerol is mediated via PPAR-gamma. $\mathrm{Br} J$ Pharmacol (2011) 163:1533-49. doi:10.1111/j.1476-5381.2011.01444.x

100. Sancho R, Calzado MA, Di Marzo V, Appendino G, Munoz E. Anandamide inhibits nuclear factor-kappaB activation through a cannabinoid receptor-independent pathway. Mol Pharmacol (2003) 63:429-38. doi:10.1124/ mol.63.2.429

101. Murphy N, Cowley TR, Blau CW, Dempsey CN, Noonan J, Gowran A, et al. The fatty acid amide hydrolase inhibitor URB597 exerts anti-inflammatory effects in hippocampus of aged rats and restores an age-related deficit in long-term potentiation. J Neuroinflammation (2012) 9:79. doi:10.1186/1742-2094-9-79

102. Marchalant Y, Brothers HM, Norman GJ, Karelina K, DeVries AC, Wenk GL. Cannabinoids attenuate the effects of aging upon neuroinflammation and neurogenesis. Neurobiol Dis (2009) 34:300-7. doi:10.1016/j.nbd.2009.01.014

103. Henry RJ, Kerr DM, Finn DP, Roche M. For whom the endocannabinoid tolls: modulation of innate immune function and implications for psychiatric disorders. Prog Neuropsychopharmacol Biol Psychiatry (2016) 64:167-80. doi:10.1016/j.pnpbp.2015.03.006

104. Herring AC, Kaminski NE. Cannabinol-mediated inhibition of nuclear factor-kappaB, cAMP response element-binding protein, and interleukin-2 secretion by activated thymocytes. J Pharmacol Exp Ther (1999) 291:1156-63.

105. Rossi S, Motta C, Musella A, Centonze D. The interplay between inflammatory cytokines and the endocannabinoid system in the regulation of synaptic transmission. Neuropharmacology (2015) 96:105-12. doi:10.1016/j. neuropharm.2014.09.022

106. Arevalo-Martin A, Garcia-Ovejero D, Sierra-Palomares Y, Paniagua-Torija B, Gonzalez-Gil I, Ortega-Gutierrez S, et al. Early endogenous activation of $\mathrm{CB} 1$ and $\mathrm{CB} 2$ receptors after spinal cord injury is a protective response involved in spontaneous recovery. PLoS One (2012) 7:e49057. doi:10.1371/ journal.pone.0049057

107. Ramírez BG, Blazquez C, Gomez del Pulgar T, Guzman M, de Ceballos ML. Prevention of Alzheimer's disease pathology by cannabinoids: neuroprotection mediated by blockade of microglial activation. J Neurosci (2005) 25:1904-13. doi:10.1523/JNEUROSCI.4540-04.2005

108. Martín-Moreno AM, Reigada D, Ramirez BG, Mechoulam R, Innamorato N, Cuadrado A, et al. Cannabidiol and other cannabinoids reduce microglial activation in vitro and in vivo: relevance to Alzheimer's disease. Mol Pharmacol (2011) 79:964-73. doi:10.1124/mol.111.071290

109. Valenzano KJ, Tafesse L, Lee G, Harrison JE, Boulet JM, Gottshall SL, et al. Pharmacological and pharmacokinetic characterization of the cannabinoid receptor 2 agonist, GW405833, utilizing rodent models of acute and chronic pain, anxiety, ataxia and catalepsy. Neuropharmacology (2005) 48:658-72. doi:10.1016/j.neuropharm.2004.12.008

110. García-Gutiérrez MS, Manzanares J. Overexpression of CB2 cannabinoid receptors decreased vulnerability to anxiety and impaired anxiolytic action of alprazolam in mice. J Psychopharmacol (2011) 25:111-20. doi:10.1177/0269881110379507

111. Ortega-Alvaro A, Aracil-Fernandez A, Garcia-Gutierrez MS, Navarrete F, Manzanares J. Deletion of CB2 cannabinoid receptor induces schizophrenia-related behaviors in mice. Neuropsychopharmacology (2011) 36:1489-504. doi:10.1038/npp.2011.34

112. García-Gutiérrez MS, Garcia-Bueno B, Zoppi S, Leza JC, Manzanares J. Chronic blockade of cannabinoid CB2 receptors induces anxiolytic-like actions associated with alterations in GABA(A) receptors. Br J Pharmacol (2012) 165:951-64. doi:10.1111/j.1476-5381.2011.01625.x

113. Zoppi S, Perez Nievas BG, Madrigal JL, Manzanares J, Leza JC, Garcia-Bueno B. Regulatory role of cannabinoid receptor 1 in stress-induced excitotoxicity and neuroinflammation. Neuropsychopharmacology (2011) 36:805-18. doi:10.1038/npp.2010.214

114. Zoppi S, Madrigal JL, Caso JR, Garcia-Gutierrez MS, Manzanares J, Leza JC, et al. Regulatory role of the cannabinoid CB2 receptor in stress-induced 
neuroinflammation in mice. BrJPharmacol(2014) 171:2814-26. doi:10.1111/ bph. 12607

115. Walter L, Franklin A, Witting A, Wade C, Xie Y, Kunos G, et al. Nonpsychotropic cannabinoid receptors regulate microglial cell migration. J Neurosci (2003) 23:1398-405.

116. Fernández-Ruiz J, Pazos MR, Garcia-Arencibia M, Sagredo O, Ramos JA. Role of CB2 receptors in neuroprotective effects of cannabinoids. Mol Cell Endocrinol (2008) 286:S91-6. doi:10.1016/j.mce.2008.01.001

117. Romero-Sandoval EA, Horvath R, Landry RP, DeLeo JA. Cannabinoid receptor type 2 activation induces a microglial anti-inflammatory phenotype and reduces migration via MKP induction and ERK dephosphorylation. Mol Pain (2009) 5:25. doi:10.1186/1744-8069-5-25

118. Molina-Holgado F, Pinteaux E, Moore JD, Molina-Holgado E, Guaza C, Gibson RM, et al. Endogenous interleukin-1 receptor antagonist mediates anti-inflammatory and neuroprotective actions of cannabinoids in neurons and glia. J Neurosci (2003) 23:6470-4.

119. Akirav I. Cannabinoids and glucocorticoids modulate emotional memory after stress. Neurosci Biobehav Rev (2013) 37:2554-63. doi:10.1016/j. neubiorev.2013.08.002

120. Frank MG, Thompson BM, Watkins LR, Maier SF. Glucocorticoids mediate stress-induced priming of microglial pro-inflammatory responses. Brain Behav Immun (2012) 26:337-45. doi:10.1016/j.bbi.2011.10.005

121. Carrillo-de Sauvage MA, Maatouk L, Arnoux I, Pasco M, Sanz Diez A, Delahaye $\mathrm{M}$, et al. Potent and multiple regulatory actions of microglial glucocorticoid receptors during CNS inflammation. Cell Death Differ (2013) 20:1546-57. doi:10.1038/cdd.2013.108

122. Bowles NP, Hill MN, Bhagat SM, Karatsoreos IN, Hillard CJ, McEwen BS. Chronic, noninvasive glucocorticoid administration suppresses limbic endocannabinoid signaling in mice. Neuroscience (2012) 204:83-9. doi:10.1016/j. neuroscience.2011.08.048

123. Perry VH. The influence of systemic inflammation on inflammation in the brain: implications for chronic neurodegenerative disease. Brain Behav Immun (2004) 18:407-13. doi:10.1016/j.bbi.2004.01.004

124. Dantzer R, O'Connor JC, Freund GG, Johnson RW, Kelley KW. From inflammation to sickness and depression: when the immune system subjugates the brain. Nat Rev Neurosci (2008) 9:46-56. doi:10.1038/nrn2297

125. Roche M, Diamond M, Kelly JP, Finn DP. In vivo modulation of LPSinduced alterations in brain and peripheral cytokines and HPA axis activity by cannabinoids. J Neuroimmunol (2006) 181:57-67. doi:10.1016/j. jneuroim.2006.08.001

126. Ma L, Jia J, Liu X, Bai F, Wang Q, Xiong L. Activation of murine microglial N9 cells is attenuated through cannabinoid receptor CB2 signaling. Biochem Biophys Res Commun (2015) 458:92-7. doi:10.1016/j.bbrc.2015.01.073

127. Fishbein-Kaminietsky M, Gafni M, Sarne Y. Ultralow doses of cannabinoid drugs protect the mouse brain from inflammation-induced cognitive damage. J Neurosci Res (2014) 92:1669-77. doi:10.1002/jnr.23452

128. Carrier EJ, Kearn CS, Barkmeier AJ, Breese NM, Yang W, Nithipatikom $\mathrm{K}$, et al. Cultured rat microglial cells synthesize the endocannabinoid 2arachidonylglycerol, which increases proliferation via a CB2 receptor-dependent mechanism. Mol Pharmacol (2004) 65:999-1007. doi:10.1124/ mol.65.4.999

129. Silins E, Horwood LJ, Patton GC, Fergusson DM, Olsson CA, Hutchinson DM, et al. Young adult sequelae of adolescent cannabis use: an integrative analysis. Lancet Psychiatry (2014) 1:286-93. doi:10.1016/S2215-0366(14)70307-4

130. Cass DK, Flores-Barrera E, Thomases DR, Vital WF, Caballero A, Tseng KY. $\mathrm{CB} 1$ cannabinoid receptor stimulation during adolescence impairs the maturation of GABA function in the adult rat prefrontal cortex. Mol Psychiatry (2014) 19:536-43. doi:10.1038/mp.2014.14

131. Zamberletti E, Gabaglio M, Prini P, Rubino T, Parolaro D. Cortical neuroinflammation contributes to long-term cognitive dysfunctions following adolescent delta-9-tetrahydrocannabinol treatment in female rats. Eur Neuropsychopharmacol (2015) 25:2404-15. doi:10.1016/j. euroneuro.2015.09.021

132. Lopez-Rodriguez AB, Llorente-Berzal A, Garcia-Segura LM, Viveros MP. Sex-dependent long-term effects of adolescent exposure to THC and/or MDMA on neuroinflammation and serotoninergic and cannabinoid systems in rats. Br J Pharmacol (2014) 171:1435-47. doi:10.1111/bph.12519

133. Mizuno T, Kurotani T, Komatsu Y, Kawanokuchi J, Kato H, Mitsuma N, et al. Neuroprotective role of phosphodiesterase inhibitor ibudilast on neuronal cell death induced by activated microglia. Neuropharmacology (2004) 46:404-11. doi:10.1016/j.neuropharm.2003.09.009

134. Campos AC, Moreira FA, Gomes FV, Del Bel EA, Guimaraes FS. Multiple mechanisms involved in the large-spectrum therapeutic potential of cannabidiol in psychiatric disorders. Philos Trans R Soc Lond B Biol Sci (2012) 367:3364-78. doi:10.1098/rstb.2011.0389

135. Izzo AA, Borrelli F, Capasso R, Di Marzo V, Mechoulam R. Non-psychotropic plant cannabinoids: new therapeutic opportunities from an ancient herb. Trends Pharmacol Sci (2009) 30:515-27. doi:10.1016/j.tips.2009.07.006

136. Gomes FV, Llorente R, Del Bel EA, Viveros MP, Lopez-Gallardo M, Guimaraes FS. Decreased glial reactivity could be involved in the antipsychotic-like effect of cannabidiol. Schizophr Res (2015) 164:155-63. doi:10.1016/j. schres.2015.01.015

137. Gomes FV, Issy AC, Ferreira FR, Viveros MP, Del Bel EA, Guimaraes FS. Cannabidiol attenuates sensorimotor gating disruption and molecular changes induced by chronic antagonism of NMDA receptors in mice. Int $J$ Neuropsychopharmacol (2015) 18:1-10. doi:10.1093/ijnp/pyu041

138. Fillman SG, Cloonan N, Miller LC, Weickert CS. Markers of inflammation in the prefrontal cortex of individuals with schizophrenia. Mol Psychiatry (2013) 18:133. doi:10.1038/mp.2012.110

139. Muguruza C, Lehtonen M, Aaltonen N, Morentin B, Meana JJ, Callado LF. Quantification of endocannabinoids in postmortem brain of schizophrenic subjects. Schizophr Res (2013) 148:145-50. doi:10.1016/j. schres.2013.06.013

140. Giuffrida A, Leweke FM, Gerth CW, Schreiber D, Koethe D, Faulhaber J, et al. Cerebrospinal anandamide levels are elevated in acute schizophrenia and are inversely correlated with psychotic symptoms. Neuropsychopharmacology (2004) 29:2108-14. doi:10.1038/sj.npp.1300558

141. Leweke FM, Piomelli D, Pahlisch F, Muhl D, Gerth CW, Hoyer C, et al. Cannabidiol enhances anandamide signaling and alleviates psychotic symptoms of schizophrenia. Transl Psychiatry (2012) 2:e94. doi:10.1038/tp.2012.15

142. Ishiguro H, Horiuchi Y, Ishikawa M, Koga M, Imai K, Suzuki Y, et al Brain cannabinoid CB2 receptor in schizophrenia. Biol Psychiatry (2010) 67:974-82. doi:10.1016/j.biopsych.2009.09.024

143. Bioque M, García-Bueno B, Macdowell KS, Meseguer A, Saiz PA, Parellada M, et al.; FLAMM-PEPs study-Centro de Investigacion Biomedica en Red de Salud Mental. Peripheral endocannabinoid system dysregulation in first-episode psychosis. Neuropsychopharmacology (2013) 38:2568-77. doi:10.1038/npp.2013.165

144. Khella R, Short JL, Malone DT. CB2 receptor agonism reverses MK-801induced disruptions of prepulse inhibition in mice. Psychopharmacology (Berl) (2014) 231:3071-87. doi:10.1007/s00213-014-3481-x

Conflict of Interest Statement: The authors declare that the research was conducted in the absence of any commercial or financial relationships that could be construed as a potential conflict of interest.

Copyright ( 2016 Lisboa, Gomes, Guimaraes and Campos. This is an open-access article distributed under the terms of the Creative Commons Attribution License (CC $B Y)$. The use, distribution or reproduction in other forums is permitted, provided the original author(s) or licensor are credited and that the original publication in this journal is cited, in accordance with accepted academic practice. No use, distribution or reproduction is permitted which does not comply with these terms. 